\title{
Correction to: Outpatient before inpatient-the good, the bad and the ugly
}

\author{
Kim Tai Vuong · Laura C. Guglielmetti · Thomas G. Albert · Waldemar Brillat Arce · Ralph F. Staerkle • \\ Raphael N. Vuille-dit-Bille (D)
}

Published online: 11 December 2020

(c) The Author(s) 2020

\section{Correction to: \\ Eur Surg 2020 \\ https://doi.org/10.1007/s10353-020-00656-X}

Due to a technical problem, the article "Outpatient before inpatient-the good, the bad and the ugly", written by Kim Tai Vuong, Laura C. Guglielmetti, Thomas G. Albert, Waldemar Brillat Arce, Ralph F. Staerkle, Raphael N. Vuille-dit-Bille was originally published electronically on the publisher's internet portal on 20 October 2020 without open access. The copyright of the article changed on 20 November 2020 to (C) The Author(s) 2020 and the article is forthwith distributed under a Creative Commons Attribution 4.0 International License, which permits use, sharing, adaptation, distribution and reproduction in any medium or format, as long as you give appropriate credit to the original author(s) and the source, provide a link to the Creative Commons licence, and

The online version of the original article can be found under https://doi.org/10.1007/s10353-020-00656-x.

\section{K. T. Vuong \\ Faculty of Medicine, University of Basel, Basel, Switzerland}

\section{C. Guglielmetti}

Department of Visceral and Thoracic Surgery, Cantonal

Hospital of Winterthur, Winterthur, Switzerland

\section{T. G. Albert}

Attorney-at-law, Zurich-Kusnacht, Zurich, Switzerland

W. Brillat Arce $\cdot$ R. N. Vuille-dit-Bille, MD, PhD ( ()

Department of Pediatric Surgery, University Children's

Hospital Basel (UKBB), Spitalstrasse 33, 4056 Basel,

Switzerland

rnvuille@gmail.com

\section{R. F. Staerkle}

Clarunis Department of Visceral Surgery, University of Basel, Basel, Switzerland indicate if changes were made. The images or other third-party material in this article are included in the article's Creative Commons licence, unless indicated otherwise in a credit line to the material. If material is not included in the article's Creative Commons licence and your intended use is not permitted by statutory regulation or exceeds the permitted use, you will need to obtain permission directly from the copyright holder. To view a copy of this licence, visit http://creativecommons.org/licenses/by/4.0/.

Open Access This article is licensed under a Creative Commons Attribution 4.0 International License, which permits use, sharing, adaptation, distribution and reproduction in any medium or format, as long as you give appropriate credit to the original author(s) and the source, provide a link to the Creative Commons licence, and indicate if changes were made. The images or other third party material in this article are included in the article's Creative Commons licence, unless indicated otherwise in a credit line to the material. If material is not included in the article's Creative Commons licence and your intended use is not permitted by statutory regulation or exceeds the permitted use, you will need to obtain permission directly from the copyright holder. To view a copy of this licence, visit http://creativecommons.org/licenses/by/4.0/. 